\title{
The EU Reinsurance Directive
}

\author{
Alastair M. Evans \\ Head, Government Affairs, Lloyd's Worldwide Markets, One Lime Street, London EC3M 7HA, U.K. \\ E-mail: Alastair.M.Evans@lloyds.com
}

The commentary briefly traces the history of the debate leading to the adoption of the EU Reinsurance Directive in November 2005, outlines its major provisions and attempts to assess the possible significance and impact of the Directive on the EU internal market and on the EU's relations with third countries. It also notes the various factors that persuaded the European insurance industry and the EU that a common approach to the regulation of reinsurers within the EU was desirable. It outlines the primary purposes of the Directive and details the regulatory approach adopted by it. It comments briefly on the timetable being followed by some Member States for implementation of the Directive into domestic law.

The Geneva Papers (2007) 32, 95-104. doi:10.1057/palgrave.gpp.2510119

Keywords: EU Reinsurance Directive; OECD; IAIS

\section{Introduction}

The purpose of this commentary is to review the background to and history of the debate leading to the adoption by the European Union (EU) of the Reinsurance Directive ("the Directive"), to outline its major provisions, and to attempt an initial assessment of the Directive's likely impact, within the European Union and on the global regulatory and trading stage.

\section{Regulation of reinsurers in the EU prior to adoption of the Directive and the debate leading to its adoption}

The EU Reinsurance Directive $(2005 / 68 / E C)^{1}$ was agreed by the EU Council of Ministers on 16 November 2005. It was published in the Official Journal of the European Union on 9 December 2005 and entered into force the following day. Member States are required to comply with its provisions by 10 December 2007.

The Directive represents the culmination of several years of discussion between the European Commission, the European Parliament, Member States, industry and others as to how reinsurance in the EU should be regulated. Yet it is not the first EU Directive to address reinsurance. That distinction belongs to a 1964 Directive $(64 / 225 / \text { EEC })^{2}$ on "abolition of restrictions on freedom of establishment and freedom to provide services in respect of reinsurance and retrocession". The 1964

\footnotetext{
${ }^{1}$ EU Council of Ministers (2005).

${ }^{2}$ EU Council of Ministers (1964).
} 
Directive's purpose was market liberalisation, to establish the general legal principle that restrictions to the transaction of reinsurance, whether by way of establishment or freedom of services, should be abolished in the EEC as should certain specific named national barriers in Belgium, Denmark, France, Germany, Luxembourg and Italy.

The 1964 Directive did not seek to create a common regulatory framework for the supervision of reinsurance within the then European Economic Community. It did not therefore lay down any requirements for Member States to observe in respect of authorisation of reinsurers established in the Community or conditions governing the transaction of reinsurance business.

It took another 41 years before the EU adopted the Directive and addressed the issue of how reinsurers established in the EU should be regulated. It might reasonably be asked why there was such a long interval between these two reinsurance directives. It was because the EU's focus in the intervening decades was on creating a single market for direct insurance. There was political and commercial logic in focusing first on direct insurance: the benefits of a single market in insurance would be perceived and enjoyed directly by European citizens if they had the choice of a larger number of providers and a more competitive range of products and prices as a result of removing internal barriers to trade. Attainment of such benefits was therefore politically more attractive than the regulation of a sector involving business to business transactions.

It is not the purpose of this article to review the process by which the single market in direct insurance was gradually constructed. Suffice to say that this proved not to be a straightforward venture. It entailed the adoption, often after vigorous debate, of a number of Directives, both for non-life and life, which progressively gave effect to the rights of establishment and freedom to provide services and, via the so-called third generation of Directives in the early 1990s, created the Home State authorisation, passport and financial supervisory system which applies today to direct writers of insurance established within the EU.

These Directives, adopted between the 1970s and 1990s, did not ignore reinsurance altogether. Indeed, under the Directives, direct insurers established in the EU, which write reinsurance ("mixed insurers") became subject to the exclusive financial supervisory system of their home Member State in respect of their entire business, just like direct insurers.

\section{Increasing international debates on reinsurance and reinsurer regulation}

From the mid-1990s onwards, however, a sea change occurred, brought about by an increasing focus on reinsurance issues in various international fora, such as the Organisation for Economic Co-operation and Development (OECD), the Financial Stability Forum (FSF), the International Association of Insurance Supervisors (IAIS) and the World Trade Organisation (WTO). The importance of reinsurance to many direct insurers' financial strength and stability came to be increasingly appreciated as did its overall role and importance in the global financial system, reaffirmed in recent years by its substantial absorption of catastrophic losses from various man-made and 
natural events. This focus led to the adoption of a number of rules by international organisations seeking to regulate supervision of reinsurers, cedant interaction with reinsurers, and the cross-border provision of reinsurance and retrocession. These rules included an OECD recommendation on reinsurance in $1998^{3}$ as well as two IAIS reinsurance standards in 2002 and $2003 .^{4}$

The OECD recommended that member countries invite insurance companies under their supervision to take all appropriate steps to assess the soundness of their reinsurers. The recommendation referred to a number of possible sources of information, including annual reports and publicly disclosed regulatory submissions. It also established a list of factors to be considered in the evaluation, including the legal and statutory framework of the reinsurer, ownership/shareholders, management, performance indicators, technical provisions, solvency and investments.

The IAIS supervisory standard on the evaluation of the reinsurance cover of primary insurers and the security of their reinsurers of January 2002 is intended to ensure that the primary insurer has an effective reinsurance strategy in place, covering selection of reinsurers and assessment of their financial security. The standard recommends that supervisors evaluate the effectiveness of the reinsurance cover as well as the security of the reinsurers selected.

The IAIS standard on supervision of reinsurers of 2003 focuses specifically on areas where reinsurers differ from primary insurers and indicates that the supervisory framework needs to be adapted to take into account reinsurance characteristics with regard to technical provisions, investments and liquidity, economic capital requirements, and corporate governance (policies regarding risk management and control). It also calls for an exchange of information between supervisors and encourages the establishment of a database on reinsurers.

\section{The EU debate on reinsurer regulation}

Against this background of growing international interest in reinsurer regulation and the role of reinsurance in financial stability, the fragmented approach within the EU, whereby the regulation of "pure" reinsurers (i.e., those which only wrote reinsurance business) was determined at national level, seemed increasingly out of step with the tenor of international debates. Furthermore, this fragmentation deprived the EU of being able to speak with one voice, despite the leading role occupied by the European reinsurance industry as a whole in the global provision of reinsurance.

It was the British and German insurance industries, which first perceived, at private sector level, the need to debate whether the EU should be encouraged to adopt a common approach to the regulation of reinsurers. The arguments in the debate were by no means one-sided. Amongst other issues it was suggested that national regulatory systems of reinsurers, where they existed, had not proved deficient; that there was no need to impose additional layers of regulation on a sector which involved business to

\footnotetext{
${ }^{3}$ OECD Council on assessment of reinsurance companies (1998)

${ }^{4}$ IAIS Reinsurance Sub-committee (2002) and IAIS (2003).
} 
business transactions and did not entail direct contact with consumers; and that indeed there was a risk that cedants might derive false security from the fact of a reinsurer having been nationally authorised, with the consequent risk that the cedant might not carry out the full array of checks on the quality and financial strength of its reinsurer that prudence ought to dictate.

In the end, notwithstanding these arguments, a consensus gradually evolved within the EU insurance and reinsurance industry that the advantages of an EU common approach to regulation of reinsurers outweighed its disadvantages and that it was highly desirable to fill this lacuna in EU law. The Comité Européen des Assurances (CEA) concluded that it would be desirable for the EU to develop a reinsurance Directive and suggested that the existing insurance Directives might serve as a fasttrack model for the regulation of reinsurers. This conclusion was submitted to the European Commission by the CEA and by national EU insurer associations to their Governments, together with suggestions as to the subject matter EU regulation should address.

The European Commission agreed with the CEA's view that reinsurers established in the EU should be subject to common EU rules of regulation and that the existing insurance directives should serve as a model. This commentary will not attempt to trace the debate ensuing on the Commission's proposal for a Directive in April 2004, its consideration by the European Parliament and Economic and Social Committee and its discussion and eventual adoption by Member States. Inevitably, this process gave rise to discussions between participants on the detail of reinsurer regulation deemed necessary or desirable. These discussions were resolved with the adoption of the Directive in late 2005.

Two additional background considerations underlay the debate about the Directive's contents.

First, recognition of the nature of reinsurance itself as a mechanism for the spreading of risk globally. The Directive itself recognises reinsurance is a major financial activity. By facilitating a wider distribution of risks at worldwide level, it allows direct insurers to have a higher underwriting capacity to provide insurance cover as well as reducing their capital costs. Also, it acknowledges that reinsurance plays a fundamental role in financial stability since it is an essential element in ensuring the financial soundness and the stability of direct insurance markets, a point also recently recognised in the 2006 Group of Thirty report entitled Reinsurance and International Financial Markets. ${ }^{5}$

Second, as mentioned above, there were different traditions of reinsurance regulation within the EU at the outset of the debate. Some Member States (e.g., Denmark, Portugal and the UK) regulated reinsurers more or less in the same way as they regulated direct insurers. Other Member States (e.g., Belgium, Greece and Ireland) placed the primary responsibility on cedants to satisfy themselves as to the financial strength and trustworthiness of their commercial counterparties, the reinsurers. Other Member States adopted approaches that combined features of direct regulation of reinsurers with the indirect cedant approach.

\footnotetext{
${ }^{5}$ Group of Thirty (2006).
} 


\section{Purpose and content of the directive}

The Directive has four primary purposes:

(1) To provide a single market for reinsurance in the EU. The EU's Action Plan for Financial Services had identified reinsurance as a sector, which required action at community level in order to complete the internal market for financial services.

(2) To ensure minimum common standards for the regulation of reinsurers established in the EU. As the Directive's preamble notes, there were divergences between national provisions regarding prudential regulation of reinsurance, a situation which "has resulted in significant differences in the level of supervision of reinsurance undertakings in the community which creates barriers to the pursuit of reinsurance business".

(3) To incorporate reinsurance into the EU's supervisory system of the insurance sector prior to adoption of the Solvency II proposals. Solvency II will update the existing solvency rules for the EU insurance sector and should result in the introduction of more risk-based capital-setting requirements for the industry. The incorporation of the EU reinsurance sector into a common EU supervisory structure was seen as a necessary and logical step to creating updated solvency rules applicable to the whole insurance and reinsurance sector.

(4) To strengthen the EU in negotiations with third country (i.e., non-EU) jurisdictions. The adoption of a common regulatory system would enable the EU to present a united front when participating in debates on reinsurance regulation in international fora and with third countries. Put another way, the prior fragmented system of uncoordinated national approaches inhibited the EU in such debates.

The Directive applies to pure reinsurers, captive reinsurers and special purpose vehicles. As stated above, "mixed" insurers are subject to the financial supervisory system of their home Member State under the existing EU insurance directives, but the Directive amends the existing insurance Directives so as to introduce requirements, which apply in respect of the reinsurance business of a mixed insurer where such business exceeds certain size criteria.

The Directive deals with the following subjects: scope and definitions; the taking up of reinsurance and authorisation of the reinsurance undertaking; conditions governing the business of reinsurance; finite reinsurance and special purpose vehicles; right of establishment and freedom to provide reinsurance services; reinsurance undertakings whose head offices are outside the Community and which conduct reinsurance activities in the Community; subsidiaries of parent undertakings governed by the laws of a third country and acquisitions of holdings by such parent undertakings; other provisions; amendments to existing directives; and transitional and final provisions.

The directive has both EU internal market and external aspects. In terms of its impact on the EU internal market, the following features of the regime created by the Directive might be highlighted. It follows the overall model of 
the insurance supervisory regime for direct insurers and mixed insurers created by the existing Insurance Directives. It introduces a requirement for authorisation by home Member States of pure reinsurers established in the EU. The location of the headquarters of the reinsurer will determine which is the EU home State supervisor. The single licence or passport granted by the home State supervisor will enable the reinsurer to trade throughout the whole of the EU. The regime is based on mutual recognition of regulatory systems which meet the Directive's requirements, that is, the Directive follows the approach of existing EU legislation for direct insurance by carrying out "harmonisation which is essential, necessary and sufficient to ensure the mutual recognition of authorisations and prudential control systems". The home State supervisor will have exclusive responsibility for financial supervision of the reinsurer, whose head office is located in its territory: that means that a reinsurer already authorised in its home member State should not be subject to additional supervision or checks related to its financial soundness by the competent authorities of the cedant.

The Directive lays down a solvency regime, which includes general principles relating to investment rules for assets covering technical reserves with which the reinsurer must comply. It requires Member States to abolish gross reserving and pledging of assets (collateral requirements) from EU reinsurers by 10 December 2008 at the latest: in fact, only a very small minority of Member States currently require collateral from such reinsurers. The EU's complete rejection of statutorily required collateral as an appropriate instrument for the regulation of cedants' relationships with reinsurers will inevitably intensify international debate and focus on the few remaining countries worldwide which continue to favour the use of collateral in such circumstances.

The Directive also deals with the EU external dimension. The European Commission may submit proposals to the Council for possible agreements with third countries that seek to ensure "under conditions of equivalence of prudential regulation, effective market access for reinsurance undertakings in the territory of each contracting party and provide for mutual recognition of supervisory rules and practices on reinsurance".

The Commission is also required to draw up periodic reports on treatment accorded EU reinsurance undertakings in third countries. Where a third country is not granting EU reinsurers effective market access, the Commission may submit recommendations to the Council for negotiations with a view to obtaining improved access for $\mathrm{EU}$ reinsurers.

It is too early to say how the EU will use these powers but it is apparent that they may provide useful instruments to confront any discriminatory and unfair treatment that EU reinsurers face in third countries.

The reference to possible "mutual recognition of supervisory rules and practices on reinsurance" in the Directive seems particularly timely since the IAIS, via its Reinsurance Mutual Recognition Sub-group, is also discussing the subject of such possible agreements. The IAIS work consists of two parts:

- development of a framework outlining minimum principles to be considered for a system of mutual recognition of reinsurers between supervisors; and 
- a review of existing IAIS principles, standards and guidance papers in relation to supervision of reinsurers to determine whether additional guidance is required to act as a basis for a system of mutual recognition of reinsurers.

It has also been studying reinsurance regulatory rules applicable in IAIS member countries dealing with establishment of technical provisions and risk limitations; capital and surplus requirements; investments and liquidity; reporting requirements; corporate governance policies; and holding company systems.

It is too early to say what will emerge from this IAIS work but, conceivably, it may lead to the creation of a framework for the conclusion of further international mutual recognition agreements (of which the Directive itself is an example), which may in turn lessen some of the regulatory burdens internationally trading reinsurers face in certain jurisdictions.

The Directive also provides in Article 49 that a Member State shall not apply more favourable treatment to non-EU reinsurers than that accorded to reinsurers having their head office in that Member State. The treatment of non-EU reinsurers remains under individual Member State control. It remains to be seen whether non-EU reinsurers will seek in the future to operate on a branch basis in particular Member States or to incorporate in a Member State and take advantage of the "passport" enabling it to trade throughout the whole of the EU.

\section{The commercial impact of the directive}

Any attempt to assess some of the potential commercial impacts of the Directive in advance of its entry into force is necessarily speculative.

Reinsurers which wish in the future to establish within the EU will need to satisfy the Directive's regulatory and financial requirements. The possibility of taking advantage of any particular regulatory regime in the EU, which is less exacting than the Directive's requirements will disappear with the Directive's implementation. Entry into the reinsurance marketplace will therefore prove more onerous in some Member States though, of course, any particular ease of establishment of a reinsurer to date under a more benign or non-existent regulatory regime in a particular EU Member State may have been offset by the commercial imperative of the need for a good credit agency rating and the effect of counter-party evaluation. There are already indications that some non-EU reinsurers may wish to establish reinsurance companies within the EU to take advantage of passporting under the new regime created by the Directive.

A number of the world's leading reinsurers (including Munich Re, Hannover Re, Lloyd's, Allianz Re and Scor) are already established in the EU and trade globally. The major insurance groups often comprise many separate legal entities incorporated in a large number of different countries. The Directive will facilitate EU reinsurers' operations within the EU to the extent that their branch activities will no longer be subject to the separate prudential supervision of different host states. It will be simpler for such reinsurers to have to comply with one set of prudential rules operated by their home member State rather than a variety of such rules throughout the EU where they are established as branches. Where they operate through subsidiaries, the supervisor of 
the subsidiaries' Head office becomes the competent regulatory authority. Reinsurers operating through a Group structure will no doubt be carefully considering how they can more advantageously structure their operations in light of the Directive's provisions.

The emergence and growth of the Bermudan market in recent years on the global reinsurance stage suggests, however, that regulation is not the only factor that determines location of reinsurer underwriting capacity. Ability to set up underwriting operations quickly, levels of corporation tax and ease of access to particular markets, such as the U.S., can play their part too in determining choice of platform of operation.

Within the EU, reinsurance and retrocession business has been transacted for many years across frontiers without major barriers, subject to the existence of certain national collateral requirements. The Directive, although it will strengthen the EU's internal market and remove collateral requirements, may not have a marked impact in that sense.

EU countries have not generally exercised control over pricing and wordings of reinsurance contracts. The Directive's prohibition of such controls will not therefore materially change the environment of commercial freedom already available to parties to reinsurance contracts within the EU.

It remains to be seen whether the Directive spurs further consolidation in the reinsurance market. The recent merger of Swiss Re and GE Insurance Solutions, which pre-dates the implementation of the Directive, suggests that the process of consolidation in the sector may often be motivated by perceived opportunities for expansion of market presence and synergies of operation and is not wholly dependent on the regulatory environment. It is not believed that any reinsurer to date has indicated that the Directive will, of itself, bring about major consolidation trends in the EU reinsurance sector.

The global reinsurance industry has faced some tough commercial challenges in recent years, ranging from 11 September to the U.S. hurricanes in 2004 and 2005. Cycle management remains a key challenge to be faced by all reinsurers. To the extent that the Directive, strengthened by Solvency II legislation in due course, reinforces internal mechanisms of financial control, risk management and disciplined underwriting, it should strengthen reinsurers' ability to deal with the challenges of the cycle.

Cedants, which transact business with EU reinsurers (after the Directive enters into force), will have the comfort of knowing that such reinsurers are subject at least to the regulatory and financial requirements prescribed by the Directive, and may derive comfort from that fact. Yet, as the IAIS supervisory standard on the evaluation of the reinsurance cover of primary insurers and the security of their reinsurers recommends, primary insurers cannot just rely on supervisory authorisation and should in any event have an effective reinsurance strategy in place covering selection of reinsurers and assessment of their financial security. The Directive will not therefore obviate the need for primary insurers to undertake appropriate counter-party assessments.

An article in the Directive (Article 46) gives Member States discretion at national level to allow the establishment of Special Purpose Vehicles (SPVs) within their 
territories subject to the laying down of conditions under which the activities of such SPVs can be carried out. Under the Directive, these national conditions must include licensing, conduct of business, prudential, solvency and accounting requirements. Some commentators have already noted that the creation of such SPVs could give insurers and reinsurers access to more diverse sources of capital and enable them to manage their capital more efficiently, by providing an alternative to the conventional reinsurance and retrocession market for balance sheet protection. The insurance, reinsurance and capital markets are no doubt already considering how to take advantage of the commercial opportunities that SPVs established in the EU may provide.

\section{Implementation of the directive into national law}

All Member States are now legally required to implement the Directive's provisions into national law by 9 December 2007 except to the extent that the Directive permits a longer implementation period, as is the case with abolition of any national collateral system.

This date is a deadline. It does not prevent Member States from choosing to adjust the provisions of national law to conform with the Directive at an earlier date.

Indeed it is known that some Member States aim to do so or have already done so. For example, Ireland gave effect to the Directive's provisions in national law by July 2006. The UK has set itself a target of adjusting national law by the beginning of 2007.

The degree of change in national rules obviously depends on the extent to which current national rules are already aligned with the Directive's provisions. For those Member States which until now have had no national statutory systems of reinsurance regulation, the degree of legislative change needed will be considerable. For others, the changes may be less far-reaching though still significant.

The CEA and national insurer associations are playing their part in assisting Governments in this process. In this connection, for example, the CEA has prepared a paper explaining the economic and risk management benefits of insurance and reinsurance and suggesting how Member States might implement in national law the Directive's article on finite reinsurance.

\section{Conclusions}

Given that Member States have until December 2007 to implement its provisions into national law, it is of course too early to reach any definitive conclusions about the practical impact of the Directive. Nevertheless, this need not prevent an attempt to venture some initial thoughts.

It seems fair to say that the Directive is a significant and timely measure, which recognises both the increasing international focus and recent debates on reinsurance regulation and the international nature of reinsurance itself. Confronted with such debates, it was almost unthinkable for the EU not to have its own internal common view and regulatory system. 
It creates a common EU framework of reinsurance regulation and rules, which all Member States must implement and comply with.

It creates a model of an international mutual recognition system of reinsurance regulatory regimes.

It should facilitate the transaction of reinsurance business in the EU to the extent that such business might previously have been hampered by diverse national rules.

The commercial impact of the Directive is likely to be limited, at least in the shortterm.

The degree of change in national rules governing reinsurance within EU Member States, which the Directive will necessitate, depends on the extent to which such current national rules already reflect its binding provisions. For many Member States it seems that their national rules may need to be substantially amended to comply with the Directive's provisions.

It will facilitate the application of the EU's new Solvency II regime to both EU insurers and reinsurers.

Finally, by creating such a common regulatory framework within the EU and by inclusion of powers addressing relations with third countries, the Directive should strengthen the voice of the EU, both in international fora and when negotiating with third countries.

\section{References}

EU Council of Ministers (2005) Directive 2005/68/EC of the European Parliament of the Council of 16 November 2005 on reinsurance and amending Council Directives 73/239/EEC, 92/49/EEC as well as Directives 98/78/EC and 2002/83/EC, 16 November.

EU Council of Ministers (1964) Council Directive of 25 February 1964 on the abolition of restrictions on freedom of establishment and freedom to provide services in respect of reinsurance and retrocession (64/ 225/EEC), February.

Group of Thirty (2006) Reinsurance and International Financial Markets, Washington, DC: Group of Thirty. IAIS (2003) Standard on supervision of reinsurers (October 2003).

IAIS Reinsurance Sub-committee (2002) Supervisory standard on the evaluation of the reinsurance cover of primary insurers and the security of their reinsurers (January 2002).

OECD Council on assessment of reinsurance companies (1998) Recommendation of the OECD Council on assessment of reinsurance companies, adopted by the Council at its 921st session on 25 March 1998 [C/ M(98)7PROV].

\section{About the Author}

Alastair Evans is Head of Government Affairs at Lloyd's, responsible for relations with international organisations and the U.K. Government. He was Chairman of the CEA International Affairs Committee from 2001 to 2005. He has worked for Lloyd's since 1989. He holds degrees in modern history and modern languages from Oxford University and law from London University, and is a barrister. He is an Associate Member of the U.K. Chartered Insurance Institute. 